\title{
Maritime Conservation Area during COVID-19 Pandemic: The Case of Benoa Bay Bali
}

\author{
Slamet Subekti ${ }^{1 *}$, Singgih T. Sulistiyo ${ }^{2}$, and Dedi S. Adhuri ${ }^{3}$ \\ ${ }^{12}$ Department of History Faculty of Humanities Universitas Diponegoro, Indonesia \\ ${ }^{3}$ Social and Cultural Research Center, Indonesian Institute of Sciences
}

\begin{abstract}
The COVID-19 pandemic has had a wide impact on the lives of the Balinese people. The purpose of this study is to find sources of food security related to the status of Benoa Bay as a Maritime Conservation Area (MCA) during the COVID-19 pandemic, thus providing alternative livelihoods for local communities. The research is based on published secondary data collected from observations processed descriptively. The results show that local wisdom plays an important role in maintaining Benoa Bay as a sacred area for religious and cultural activities, and secondly that the determination of Benoa Bay as an MCA is strategic in managing maritime cultural areas within the framework of SDG 14, which has an impact on creating social inclusion, improving the welfare of local communities and ensuring the sustainability of marine ecosystems in the coastal areas of Bali. The third finding is that the spread of the COVID-19 pandemic is due to the high level of population mobility and the population structure of Bali, which is already relatively old and has the potential to accelerate the potential for high case fatality rates from the pandemic. Fourth, Benoa Bay has potential resources as alternative livelihoods for local communities during the COVID-19 pandemic. Based on the study results, it is recommended to tighten the possibility of spreading through the first and second rapid tests involving as many people as possible as carriers of the spread of COVID-19, both through local transmission and imported cases. Furthermore, indigenous peoples are recommended to consistently fight for the status of Benoa Bay as an MCA through a Presidential Regulation (Peraturan Presiden) to ensure the preservation of the maritime ecosystem with its potential resources.
\end{abstract}

\section{Introduction}

Indonesia is the largest archipelago in the world and has coastal and marine ecosystems that are threatened. This occurs because natural resources contained therein are carried out in ways that damage the ecosystem. In addition, overfishing has also resulted in a drastic reduction in the natural stock of fish. Thus, it is necessary to protect the marine environment so that the coast and the sea resources can be used sustainably. Protection of coastal and marine ecosystems is still lacking compared to land.

* Corresponding author: slamet.subekti@live.undip.ac.id 
Maritime Conservation Area (MCA) is known as a means of preserving marine natural resources. By protecting biota species and their habitats, MCA (Kawasan Konservasi Maritim, Indonesia) provides social and economic benefits, including the recreational and commercial sustainable use of marine resources. MCA causes several human activities to be prohibited or restricted to achieve benefits in creating the sustainability of marine ecosystems [1].

The COVID-19 pandemic, which was first discovered in Wuhan (China) in December 2019 and has hit more than 200 countries globally, has been able to destroy the foundations of bare life in health education, economy, and economy others. In Indonesia, the Managing Director of the World Bank reported that the impact of the COVID-19 pandemic was more severe than the 1997/1998 economic crisis and other crises that have occurred. A high mortality rate accompanies the morbidity rate. As a world tourist destination, Bali is very concerned about the widespread impact of the COVID-19 pandemic on economic development and job opportunities.

The spread of the COVID-19 virus has reached many countries around the world. Starting from China, the number of sufferers of this disease throughout the world continues to grow. The rapid spread of COVID-19, including in Indonesia, has flooded many people with information. Reports from the local government that during February 2020, 343 Balinese were infected with COVID-19, 232 people recovered, 107 people were still in intensive care, and four people died [2]. In turn, the COVID-19 pandemic has impacted the livelihoods of Balinese people, including in the Benoa Bay area.

The research method is based on a descriptive study that provides an overview of several single phenomena and then tries to relate these phenomena to each other, especially in relation to the COVID-19 pandemic and Benoa Bay as an MCA. The data used is sourced from data published through official sources, such as the Central Statistics Agency, Government Agencies (especially the Bali Provincial Government), and the media. Data were collected through non-participant observation, then processed descriptively.

The discussion in this paper is divided into four parts, and the first is related to maritime conservation policy. Second, the COVID-19 pandemic in the province of Bali. Third, Benoa Bay as MCA, and fourth Benoa Bay and source of community livelihoods.

\section{Maritime Conservation Policy}

It is estimated that $87 \%$ of the world's oceans are significantly affected by human activities. In 2010 the Strategic Plan for the Convention on Biological Diversity (CBD) set a target for 2020 , which proclaims $10 \%$ of the world's coasts and high seas to be conserved through a maritime area conservation system. This global MPA target has increased substantially in recent years to the point that it is considered the "cornerstone" of marine conservation. It is estimated that in 2017 about $13 \%$ of the marine environment under national jurisdiction (up to 200 nautical miles from shore) was protected under the MPA; this is $5.3 \%$ of the total ocean area. However, estimates of global coverage vary by source and include a lower alternative figure of $3.6 \%$ of the global oceans reported as protected in actively managed MPAs [3].

Marine Protected Area is a marine area specifically dedicated to protecting and maintaining biodiversity and related natural and cultural resources and is managed through legal means or other effective means. According to the IUCN: "A clearly defined geographical space, recognized, dedicated and managed, through legal or other effective means, to achieve the longterm conservation of nature with associated ecosystem services and cultural values". Meanwhile, according to FAO: "any marine geographical area that is afforded greater protection than the surrounding waters for biodiversity conservation or fisheries management purposes will be considered an MPA". 
The MPA includes marine parks, nature reserves, and locally managed marine areas that protect reefs, seagrass beds, shipwrecks, archaeological sites, tidal lagoons, mudflats, salt marshes, mangroves, rock platforms, underwater areas on the coast and the seabed. In deep water, as well as open water columns [4].

In 1988, The World Conservation Union (IUCN) called on national governments, international agencies and the non-governmental community to:

Provide for the protection, restoration, wise use, understanding, and enjoyment of the world's marine heritage by creating a global, representative system of marine protected areas and through management following the principles of the World Conservation Strategy of human activities that use or use affect the marine environment.

In many parts of the world there is a growing focus and appreciation for the need for more MPAs and for better management of the marine and coastal environment in general.

The following identifies four categories for the MPA concept and key questions: [3].

1) Geographical areas with a sea-influenced character defined as borders, usually including the water column and the bottom of the benthic component. How big should an MPA be in order to properly capture certain features? To what extent are these limits scientifically arbitrary or rational? Did the boundary trigger change to the surrounding system? What constitutes effective "connectivity" within and between MPAs? How and to what extent does a boundary area preserve highly motile species?

2) Protection through legal means or other explicit means. What level of protection should be applied? Should a MPA or part of it be "mixed use" or "no-take"? Is there a right balance between conservation and livelihoods? What are the political implications of more or less protection? How do we measure success?

3) Features of a specific conservation or system goal. What are the specific and general objectives of the MPA? Under what circumstances might it be effective as a representative of the conservation environment, for a focus on species protection, or as a strategy to ensure broader marine ecosystems or economic benefits? Which conservation features should be defined and why? Does the current status suggest maintaining or restoring goals?

4) Management with the aim of achieving a higher level of protection compared to the surrounding area. Which management approach is optimal in conveying this objective? What constitutes effective stakeholder engagement? Where is the best balance between voluntary and conflict management approaches? Is a particular management plan adequate or achievable? In practice, with limited resources, to what extent can compliance be achieved?

The four categories of questions are general. Their application is discussed in theory and practice in many institutions ranging from international treaty organizations through national and provincial governments to non-governmental organizations (NGOs), research institutes and universities.

The government's attention to the formation of marine conservation areas was shown in the Decree of the Minister of Agriculture in 1957, which stated the enactment of the 1941 Nature Protection Ordinance. This ministerial decree emphasized that efforts to establish and manage marine conservation areas in nature reserves can be carried out based on this ordinance. Examples are the Banda Sea Nature Reserve (2,500 ha) in 1973 and Kepulauan Seribu (108,000 ha) in 1982, which later became the first marine national park in Indonesia. The determination of coastal areas, islands and coastal forests is carried out using the 1967 Basic Forestry Law, for example, Pulau Semama (Wildlife Reserve) and Pulau Sangalaki (Marine Tourism Park) to protect the coastal habitat/turtle nesting islands. 
After the 1941 Nature Protection Ordinance was declared invalid, the management of marine conservation areas was carried out based on Law No. 5 of 1990 concerning Conservation of Living Natural Resources and their Ecosystems. Then followed up with Government Regulation no. 68 of 1998 concerning Nature Reserve Areas and Nature Conservation Areas. Management is carried out in accordance with the function of the area, namely:

(1) Nature Reserve in the form of Marine Nature Reserve and Marine Wildlife Reserve.

(2) Nature Conservation Areas in the form of National Parks (Marine) and Nature Tourism Parks (Sea).

According to the needs-based study of ecological aspects and conservation management, the expansion to the sea from the terrestrial national park can be carried out according to the four forms of marine conservation areas above.

Indonesian territory consists of $70 \%$ of the marine area, divided into 11 Fishery Management Areas (Wilayah Pengelolaan Perikanan, Indonesia). Marine fish catch production grew from 2014-2018 and reached 6.72 million tons in 2018. Indonesia has a strong commitment to implementing sustainable fishing practices to preserve marine resources in line with improving the welfare of coastal communities. One approach is to ensure sustainability through the implementation of WPP management.

Challenges still come from both upstream and downstream fisheries, including fishing governance and practices. This needs to be addressed with several strategies such as optimizing catch capacity in terms of catch productivity and quality, promoting sustainable fishing practices, strengthening supply chains and tracking mechanisms, increasing the reliability of data for supply assessments and management measures, and implementing sound fisheries governance. Inclusive at the WPP, provincial, and national levels [5].

With 17 thousand islands and a coastline of 99 thousand kilometres, Indonesia is known as a mega biodiversity country. Many potential marine resources can be increased, which can benefit the community's welfare both now and in the future. Marine Protected Area (MPA), or more familiar with it as a maritime conservation area (Kawasan Konservasi Maritim, Indonesia), can provide ecological, economic and social benefits for the surrounding community. By mid-2019, Indonesia had formed 22.68 million hectares of KKM, around $6.97 \%$ of the total Indonesian waters. Indonesia has also committed to accelerating the formation and increase of $\mathrm{KKM}$ to 32.5 million hectares or around $10 \%$ of the total Indonesian water area [6].

However, to benefit from marine and fishery resources, it is not only to increase the quantity of KKM but also to pay attention to the management of the KKM that has been established. Challenges that need to be addressed are regarding the effectiveness of the management of the KKM and its human resources, management capacity, and supporting infrastructure. The participation of local communities to deal with environmental degradation, primarily caused by illegal fishing activities and marine debris, is also needed to support the goal of protecting marine ecosystems. 


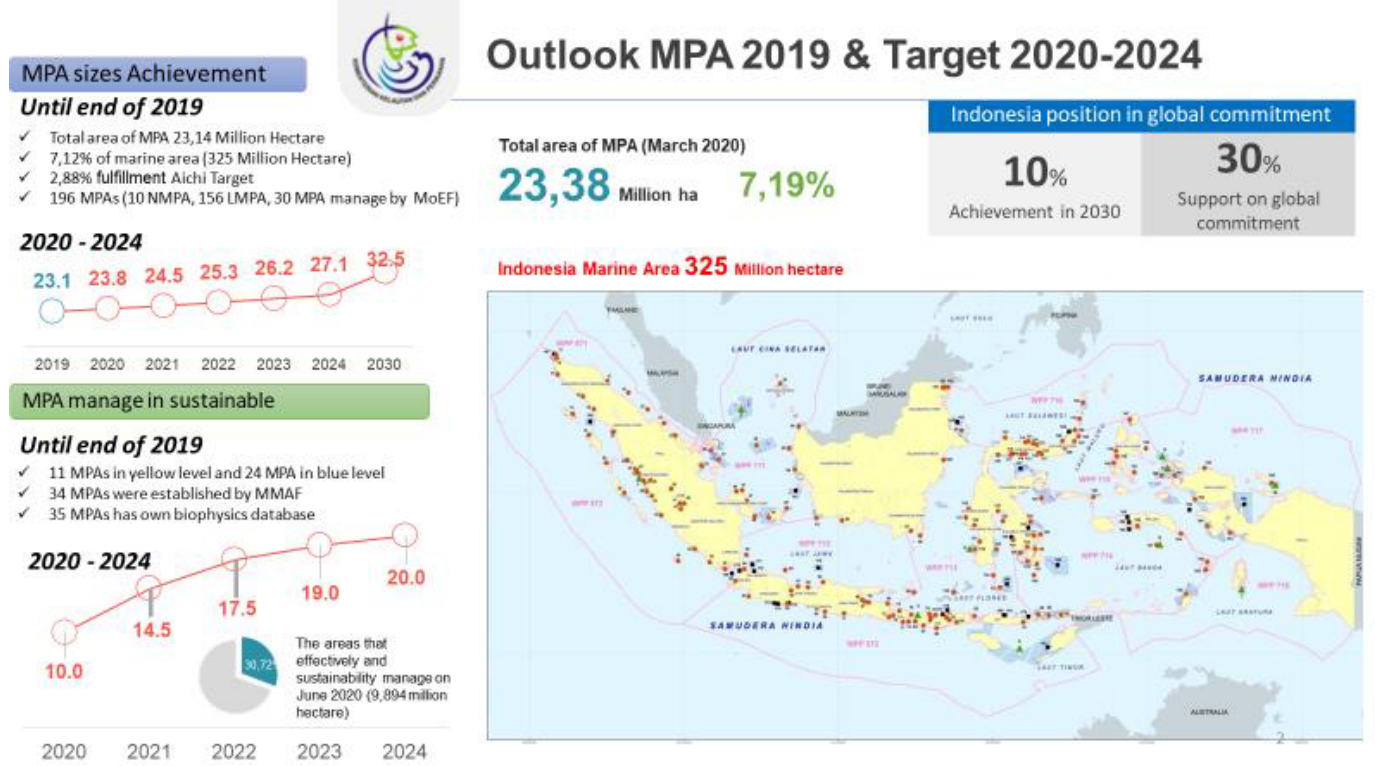

Fig. 1. Current MPA Achievements

Source: Dirjen PRL KKP 2020

\section{COVID-19 Pandemic in Bali Province}

At the end of December 2019, the World Health Organization (WHO) reported a case of pneumonia of unknown etiology in Wuhan, Hubei Province, China. After celebrating the new year on January 7, 2020, China identified pneumonia with an unknown etiology as a new type of coronavirus. The World Health Organization pneumonia cluster case with unclear etiology in Wuhan City has become a world health problem. The spread of this outbreak continued to grow until it was finally discovered that the cause of this pneumonia cluster was the coronavirus. This pandemic continues to grow until there are reports of new deaths and cases outside China. On January 30, 2020, WHO declared COVID-19 a Public Health Emergency of International Concern (PHEIC). On February 12, 2020, WHO officially designated this new human coronavirus disease as Coronavirus Disease (COVID-19).

COVID-19 is caused by SARS-COV2, which belongs to the large family of coronaviruses that caused SARS in 2003, only with a different virus type. Symptoms are similar to SARS, but the death rate for SARS $(9.6 \%)$ is higher than for COVID-19 (currently less than 5\%), although the number of cases of COVID-19 is much higher than that of SARS. COVID-19 also has a wider and faster spread to several countries than SARS [2].

Cases of the COVID-19 disease outbreak in several countries such as Singapore, Malaysia, China, Vietnam have decreased but increased in other countries, including Europe, America and Indonesia. In Bali, the COVID-19 outbreak continues to increase every day. Data from local governments shows the latest data per day. For 60 days, 343 Balinese were infected with COVID-19, 232 people recovered, 107 were still in intensive care, and 4 died. New cases from the Corona pandemic in Indonesia have shown a significant decline since late April. However, new cases in other regions, including Bali, showed a significant increase. This indicates that the centre of the spread of the virus has shifted from big cities such as Jakarta, Bandung and Surabaya to several other cities or regions throughout Indonesia. Several areas in Bali, such as Denpasar, Badung, Gianyar and other areas as new distribution centres. Until the 60th day chart, the number of sufferers in Bali has not yet 
reached its peak, and it still tends to increase. However, concerns about COVID-19 are easing with the number of patients recovering after being hospitalized.

Based on the report of I Gusti Ayu Dyah Yuniati et al., that mortality rates are seen to be more common in elderly COVID-19 sufferers. It is also associated with poorer immunity compared to younger people. Even so, the actual factor that affects the death rate of people with COVID-19 is a person's chronic illness. People with a history of chronic illness are more at risk of experiencing more fatal symptoms if they have contracted the coronavirus. The symptoms experienced by someone with the COVID-19 virus in the human body in Bali are quite diverse. However, according to patient data at the hospital, fever and dry cough were the most common symptoms found in patients with the disease. Feeling tired or weak, sputum production and shortness of breath are also symptoms found in people with COVID-19. COVID-19 is very different from the common cold. Balinese people who do not understand COVID-19 tend to underestimate the coronavirus pandemic often. This happens because the symptoms are the same in both diseases. The data shows that the differences between the COVID-19 virus and the influenza virus cannot be seen directly or even be similar and sometimes misdiagnosed. The number of deaths from COVID-19 is 12 to 24 times higher than that of the common cold.

The impact of COVID-19 on the economy is also not small. The Minister of Finance of the Republic of Indonesia said that Indonesia's economic growth projection is only 2.3 per cent. In fact, in the worst situation, the economy could be minus $0.4 \%$. The reason is the decline in consumption and investment, both in the household and in the government. The coronavirus has an impact on industries in Indonesia, especially MSMEs, Tourism and Manufacturing. The outbreak of COVID-19 has made people more concerned about the environment. An unclean or dirty environment causes diseases. Efforts to prevent various diseases, including those caused by the coronavirus, need to be done together. Gotong royong with the community by cleaning the environment and other public facilities.

Based on data compiled by the Bali Provincial Manpower Office (Bali Post, April 22, 2020: 1), of the 748 companies that reported as of April 16, 2020, 52,387 employees were repatriated, 84 companies reported that 1,204 employees were laid off (Table 1). This number does not include employees who have laid off themselves and who have laid off themselves due to the economic crisis. Of those repatriated, some still receive salaries between 25 and 75 per cent, and many are sent home without pay. Likewise, many who have been laid off do not receive severance pay. This condition brings logical consequences; firstly, those who are laid off have an impact on increasing unemployment. Secondly, those unemployed are added to new unemployment due to employees being laid off and laid off, which has logical consequences for efforts to provide social security networks for them [7].

Table 1. Number of cases of employees being dismissed and terminated at Province of Bali, As of April 15, 2020

[Source: Bali Post, 22 April 2020: 1]

\begin{tabular}{l|c|c}
\hline \multicolumn{1}{c|}{ Kabupaten/Kota } & Dirumahkan (orang) & PHK (Orang) \\
\hline Jembrana & 333 & 8 \\
Tabanan & 480 & 1 \\
Badung & 28.609 & 631 \\
Gianyar & 9.813 & 177 \\
Klungkung & 682 & 6 \\
Bangli & 381 & 0 \\
Karangasem & 2.085 & 13 \\
Buleleng & 2.140 & 134 \\
Denpasar & 8.074 & 338 \\
\hline Bali & 52.387 & 1.204 \\
\hline
\end{tabular}


In the era of the COVID-19 pandemic, new creative job opportunities have emerged. These job opportunities, such as meeting the needs of masks prepared by MSMEs (UMKM, Indonesia), the emergence of home industry opportunities, such as culinary, as well as various job opportunities that are open in rural areas.

\section{Benoa Bay as Maritime Conservation Area}

Benoa Bay is tidal water located in the southern part of Bali Island. The waters of Benoa Bay after the reclamation of Serangan Island are a semi-closed bay typology because the bay's mouth has narrowed by $75 \%$. The area of Benoa Bay waters, when measured on the outer side of the coastline, is $1,988.1$ ha, which can be divided into 3 zones. Zone 1, with the bay mouth line drawn from the Benoa Harbor wharf, covers an area of 1,668.3 ha. Zone 2 between Benoa Harbor and Serangan Island covers an area of 231.3 ha. Zone 3 between Suwung Kangin and Serangan Island covers an area of 88.5 ha [8].

Benoa Bay is administratively a trans-regency/city waters, namely Denpasar City and Badung Regency. Benoa Bay waters cover 3 districts, namely South Denpasar, Kuta and South Kuta. The waters of this bay are surrounded by 12 villages, every 6 villages in Denpasar City and Badung Regency (Table 2).

Table 2. Villages around Benoa Bay

Source: BPS Provinsi Bali 2012

\begin{tabular}{|c|c|c|c|c|c|c|c|}
\hline \multirow{2}{*}{$\begin{array}{c}\text { No } \\
\text { A }\end{array}$} & \multirow{2}{*}{$\begin{array}{c}\text { Kelurahan } \\
\begin{array}{c}\text { Kota } \\
\text { Denpasar }\end{array}\end{array}$} & \multirow[b]{2}{*}{ Kecamatan } & \multirow{2}{*}{$\begin{array}{l}\text { Luas } \\
\text { (Ha) }\end{array}$} & \multirow{2}{*}{$\begin{array}{c}\text { No } \\
\text { B }\end{array}$} & Kelurahan & \multirow[b]{2}{*}{ Kecamatan } & \multirow{2}{*}{$\begin{array}{l}\text { Luas } \\
\text { (Ha) }\end{array}$} \\
\hline & & & & & Kab. Badung & & \\
\hline 1 & Sanur Kauh & $\begin{array}{l}\text { Denpasar } \\
\text { Selatan }\end{array}$ & 386 & & Tanjung Benoa & Kuta Selatan & 239 \\
\hline 2 & Sidakarya & $\begin{array}{l}\text { Denpasar } \\
\text { Selatan }\end{array}$ & 389 & & Benoa & Kuta Selatan & 2828 \\
\hline 3 & Sesetan & $\begin{array}{l}\text { Denpasar } \\
\text { Selatan }\end{array}$ & 739 & & Jimbaran & Kuta Selatan & 2030 \\
\hline 4 & Pedungan & $\begin{array}{l}\text { Denpasar } \\
\text { Selatan }\end{array}$ & 749 & & Kedongan & Kuta & 191 \\
\hline 5 & Pemogan & $\begin{array}{l}\text { Denpasar } \\
\text { Selatan }\end{array}$ & 971 & & Tuban & Kuta & 268 \\
\hline 6 & Serangan & $\begin{array}{l}\text { Denpasar } \\
\text { Selatan }\end{array}$ & 481 & & Kuta & Kuta & 782 \\
\hline
\end{tabular}

The results of the study by Suadiarta et al. (2013) concluded that in the context of conservation of coastal areas and small islands, Benoa Bay waters have important and strategic conservation values. The following are academic considerations related to the strategic position of Benoa Bay waters:

(1) Geologically, its genesis is a landscape with a unique geological structure: the combination of volcanic processes, force structure and marine processes that form the whole island of Bali as it is today. Thus, the existence of the Benoa Bay landscape has an intrinsic value that exceeds the economic value or utilization value.

(2) Post-reclamation, Serangan Island is a semi-closed bay, in which 4 rivers (Tukad Mati and Tukad Badung from the north side, and Tukad Sama and Tukad Bualu from the south side) are synonymous with "great mixtures". From the hydrological aspect, it is a reservoir (reservoir) of surface runoff from the hinterland watershed before it enters the open sea waters through the mouth of a narrow bay. Thus, the existence of Benoa Bay waters has an important function in flood management in the surrounding urban areas. 
(3) Directly related to the surrounding mangrove forests, the stability and dynamic balance of the mangrove ecosystem in this area are controlled by oceanographic processes in the bay such as tidal propagation and currents. From a bio-ecological perspective, the mangrove system and Benoa Bay waters will support the preservation of ecological processes and life support systems, protection and preservation of biodiversity and germplasm optimally.

(4) As an area, it has an important meaning from physical, biological, and impact mitigation aspects of human activities in realizing the target of conservation of coastal ecosystems and small islands in their immediate area, namely the Sanur, Serangan and Nusa Dua areas; especially in saving the existence of coral reef ecosystems. The waters of Benoa Bay are a buffer system that maintains the integrity and health of the ecosystem, coral reefs in the surrounding area from the threat of damage caused by human activities in hinterland urban areas such as pollution originating from the land.

(5) Regionally Bali together with the surrounding waters (Sanur, Serangan and Nusa Dua) play an important role in maintaining biological connectivity in the context of Bali's regional biodiversity network. The inter-regional connectivity can be described as the "Golden Triangle Area" of Bali's coastal diversity from various threats from human activities, climate change and natural disasters. So that in micro-ecology, the conservation of the coastal ecosystem of Benoa Bay and the surrounding area will further strengthen the resilience of the coastal ecosystem of Bali Island as a whole.

The government responded to academic studies and accommodated the indigenous peoples' movement through ForBALI, which strongly urged Benoa Bay's waters to be designated as KKM. KKM Benoa Bay has a total area of 1,243.41 hectares, divided into a core zone and a limited use zone. The core zone of the KKM is 15 muntig sacred points designated for religious/customary ritual activities of the community there. Meanwhile, local communities and marine tourism activities use the limited use zone for traditional fish resource utilization.

Benoa Bay has been subject to protracted polemic accompanied by demonstrations. KKP hopes that the local government of Bali Province can immediately carry out KKM management by appointing a management organization, compiling and establishing a management plan, delineation and socialization. It is hoped that the Benoa Bay KKM is expected to maintain and sustain the local wisdom, customs and religious activities of the Balinese people.

Minister of Marine Affairs and Fisheries, Susi Pudjiastuti, declared the status of Benoa Bay waters of Badung Regency, Bali, as a Maritime Conservation Area (KKM), following up on the Bali Governor's letter to the Minister of Marine Affairs and Fisheries of the Republic of Indonesia Number 523.32 / 1687 / KL / Dislautkan dated 11 September 2019 Regarding the Proposed Designation of Areas Benoa Bay Maritime Conservation. The Governor of Bali, in the letter, proposed that Benoa Bay be designated as a Maritime Conservation Area following the results of the public consultation on 6 September 2019, which was attended by groups of experts, NGOs, associations, stakeholders, sulinggih (Hindu priests) and bendesa (adat village leaders) who utilized Benoa Bay waters. Benoa Bay has been subject to protracted polemic accompanied by demonstrations.

The determination of Benoa Bay as a Maritime Conservation Area is stipulated in the Decree of the Minister of Marine Affairs and Fisheries of the Republic of Indonesia Number 46 / KEPMEN-KP / 2019 regarding the Benoa Bay KKM in Bali Province Waters dated October 4, 2019. This Decree of the Minister of Maritime Affairs and Maritime Affairs contains several points. First, establishing Benoa Bay waters as KKM in Bali Province Waters. The second point states that the Benoa Bay Maritime Conservation Area in the waters of Bali Province is managed as a Maritime Cultural Protection Area. 
Next is the third point, regulating the total area of the Maritime Cultural Protection Area, reaching 1,243.41 hectares which includes a core zone of 15 coordinate points each with a radius of approximately $50 \mathrm{~cm}$ (Sikut, Bali) and a limited use zone. On the fourth point, the Maritime Cultural Protection Area coordinates are listed in attachment I and attachment II, which are an integral part of the Ministerial Decree. Fifth, the Ministry of Marine Affairs and Fisheries appointed the Bali Provincial Government to manage the Benoa Bay Maritime Cultural Protection Area, which includes the appointment of a management organization, preparation and determination of the KKM management plan and zoning regulations [9].

In this regard, ForBALI is of the view that the Decree of the Minister of Marine Affairs and Fisheries of the Republic of Indonesia Number 46 / KEPMEN-KP / 2019 concerning the Benoa Bay Maritime Conservation Area in the waters of Bali Province is not sufficient to designate Benoa Bay as a Maritime Conservation Area fully. The shadow of Presidential Decree No. 51/2014 is still quite strong. ForBALI believes that a specific and/or equivalent legal instrument is still needed, such as a Presidential Decree which regulates the National Strategic Area Zoning Plan as a derivative of the Marine Spatial Plan / RTRL, which defines Benoa Bay as a Maritime Conservation Area [10].

Therefore, this legal instrument can invalidate Presidential Decree No. 51/2014. Furthermore, it will strengthen the RZWP3K Perda, which is currently under discussion. So, it still takes hard work and the real struggle of all Balinese people elements to ensure that Benoa Bay is legally strong as a maritime conservation area.

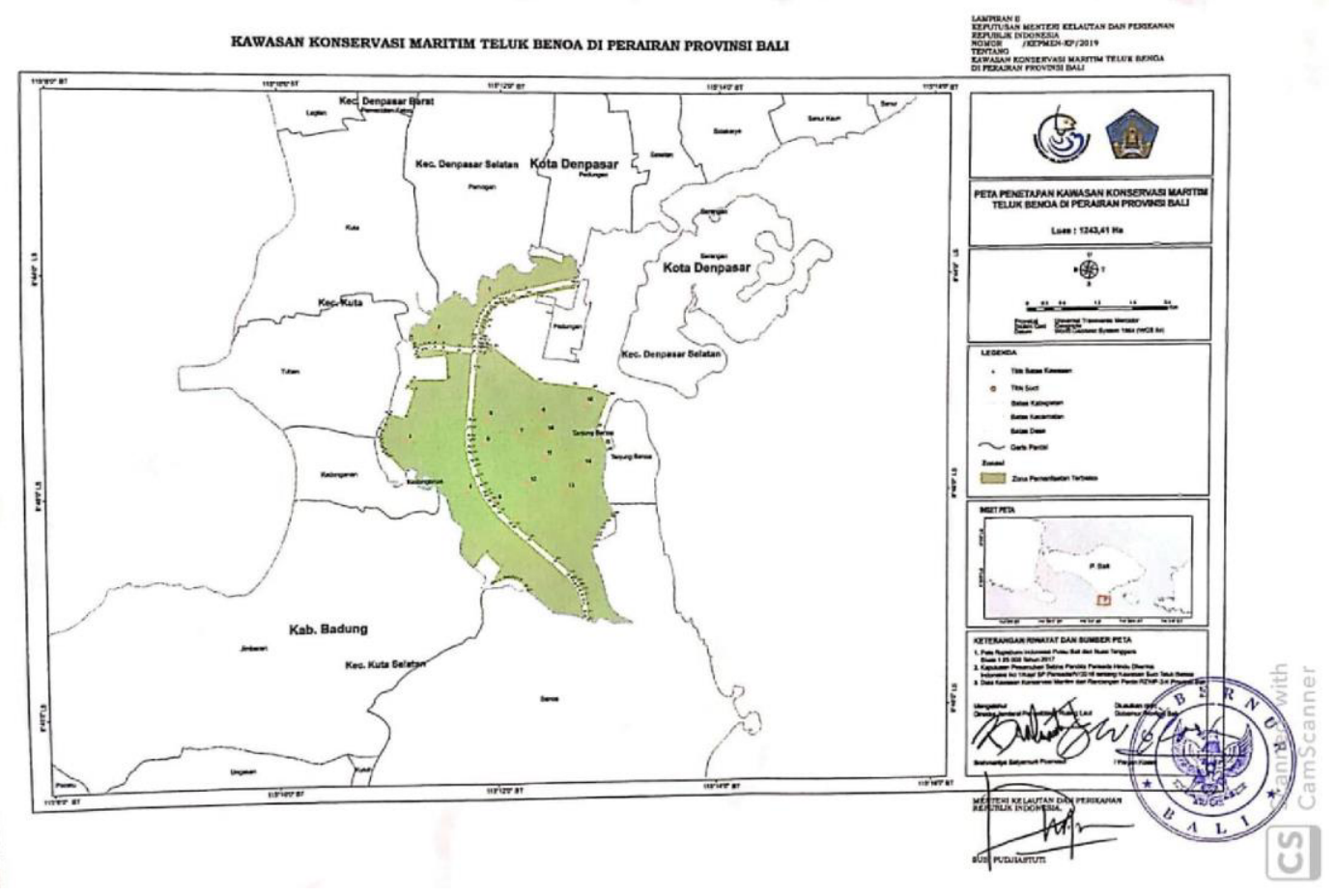

Fig. 2. Map of Benoa Bay Maritime Conservation Area

Source:

https://www.google.co.id/search?safe=strict\&hl=en\&tbm=isch\&source=hp\&biw=1280\&bih=561\&ei $=\mathrm{kgS} 3 \mathrm{X}$ ugAsTdz7sP2eK6cA\&q=tekuk+benoa+sebagai + kawasan+ konservasi+maritim 


\section{Benoa Bay and Source of Community Livelihoods}

The COVID-19 pandemic has impacted Bali's tourism industry and resulted in devastating Bali's economy. However, when income from tourism drops so that people's purchasing power decreases, Benoa Bay has meaning. For a few people who support Benoa Bay, reclamation investors consider the bay just a stretch of dirty and useless waters, so that reclamation is the answer to economic revitalization. They now understand that stone, sand and concrete are inedible. Maybe they now depend on Benoa Bay resources such as fish, crabs, shrimp and others.

For indigenous peoples who have struggled for years to maintain Benoa Bay as a sacred area, indeed, they are now increasingly convinced that Benoa Bay has economic value. They can live well from the resources of Benoa Bay. Benoa Bay provides economic benefits to local communities. If previously the bay was underestimated, now the bay is like a God of Savior who supports his people [11].

We can imagine if the indigenous people did not fight back until the bay had begun to be filled with an area of 848 hectares since the end of 2013, now there are many luxury accommodation buildings, but tourism collapses. What can be expected? Hoping that the catch from the Gulf while the Gulf has already been covered by more than half and only leaves waterways between the artificial islands?

In the view of the ForBALI movement, this COVID-19 pandemic teaches us that, when money is gone, tourists are not there when tourism dies, sand, stone, concrete, luxury buildings cannot be eaten. The pandemic teaches how to preserve Benoa Bay is to protect our lives. Therefore, all parties who have been fighting hard all this time have a stronger belief in defending Benoa Bay.

Tempo.co reported that a YouTuber named I Wayan Widyantara made seafood porridge. This porridge is rice porridge mixed with various ingredients from the sea, such as shrimp, crab, and seaweed. Wayan Widyantara said that he deliberately chose porridge because anyone can consume it, from children to the elderly. Wayan has started the culinary business in mid-2020 [12].

Tanjung Benoa Village, South Kuta District, Badung Regency, Bali, is one of the areas with abundant marine wealth. Moreover, in the South Kuta area, six porridge sellers carry different concepts. Wayan Widyantara buys fresh shrimp directly from fishers in Benoa Bay. Usually, he buys 1 to 1.5 -kilogram shrimp. He explained that the availability of shrimp depends on sea conditions. If the sea recedes at all, no fishermen will bring shrimp. It is different with crabs and seaweed that are always there every day.

Before deciding to sell seafood porridge, Wayan Widyantara had time to think about opening a popular coffee shop business with the public. However, he failed because the competition was too tight. After conducting a survey, Wayan decided to open a seafood porridge business. Opening a business during the COVID-19 pandemic is not easy because community activities have decreased, including tourist visits. As a YouTuber, he leverages the power of social media to promote seafood porridge, starting from Facebook, Instagram, Twitter, TikTok, and others.

A customer of Wayan Widyantara's seafood porridge, I Gusti Ayu Agung Indiani, said he was interested in trying the porridge after seeing its promotion on social media. Indiani was curious and proved this seafood porridge delicious. According to her, seafood porridge is more delicious if eaten on the spot. Thus, a glimpse of the emergence of new culinary variants in the Benoa Bay area. 


\section{Conclusion}

Maritime Conservation Areas (KKM) are designated as the primary protection measure for the marine environment but are a source of debate within and among stakeholder groups. In principle, sustainable development (SDGs) generates environmental and socio-economic benefits, but stakeholders prefer to view KKM as a means to seize economic opportunities. Public Understanding of the benefits of KKM in the context of marine conservation presupposes adequate education.

The active participation of stakeholders contributes to the practice of KKM for sustainable exploitation of the sea, with attention to the conservation of biodiversity. The designation of Benoa Bay as the KKM is part of the success of the indigenous people's movement and academic studies to encourage the state's commitment to achieving the national and global targets to seek 10 per cent of Indonesia's territorial waters as KKM. The prospect of Benoa Bay as a KKM in the future is expected to be in line with the goals of sustainable development with the impact of creating social inclusion, improving the welfare of local communities and ensuring the preservation of aquatic ecosystems.

Regarding that, then local wisdom plays an essential role in maintaining Benoa Bay as a sacred area for religious and cultural activities. Then the determination of Benoa Bay as an MCA is strategic in managing maritime cultural areas within the framework of SDG 14, which impacts creating social inclusion, improving the welfare of local communities and ensuring the sustainability of marine ecosystems in the coastal areas of Bali. Meanwhile, the spread of the COVID-19 pandemic is due to the high level of population mobility and the population structure of Bali, which is already relatively old, has the potential to accelerate the potential for high case fatality rates from the pandemic. Finally, Benoa Bay has potential resources as alternative livelihoods for local communities during the COVID-19 pandemic.

\section{References}

1. Romimohtarto, Kasijan, Ismu Sutanto Suwelo, Sri Murni Soenarno, Lokakarya Daerah Perlindungan Laut: Marine Protected Area (MPA) dalam Pengelolaan dan Pemanfaatannya di Indonesia. Jakarta, 4 Agustus 2004.

2. Yuniti, I Gusti Ayu Diah, Nanang Sasmita, Liris Lis Komara, Jhon Hardy Purba, Ni Putu Pandawani, "The Impact of COVID-19 on Community Life in the Province of Bali, Indonesia”. International Journal of Psychosocial Rehabilitation, Vol. 24, Issue 10, (2020).

3. Humpreys, John, Roger J.H. Herbert, "Marine protected area: Science, policy \& management". Estuarine, Coastal and Shelf Science 2015 (2018) 215-218

4. Commonwealth of Australia 2003, The Benefits of Marine Protected Area.

5. BAPPENAS, Peta Jalan SDGs Indonesia Menuju 2030. (2013)

6. Rusandi, Andi, Indonesia Marine Protected Area: Outlook and Progress. Directorate General Marine Spatial Planning, Ministry Marine Affairs and Fisheries (2020).

7. Yasa, I Gusti Wayan Murjana, "Bali in the COVID-19 Pandemic: Population and Employment Dillemas”. Jurnal Bali Membangun Bali, Vol. 1, No. 3, (2020).

8. Sudiarta, Ketut, I Gede Hendrawan, Ketut Sarjana Putra, I Made Iwan Dewantama, Kajian Modeling Dampak Perubahan Fungsi Teluk Benoa untuk Sistem Pendukung Keputusan (Decision Support System) dalam Jejaring KKP Bali. Conservation International Indonesia (2013).

9. https://www.liputan6.com/bisnis/read/4086520/kkp-tak-boleh-ada-reklamasi-dikawasan-konservasi-maritim-teluk-benoa 
10. Siaran Pers ForBALI, “Tanggapan ForBALI atas Penetapan Teluk Benoa sebagai Kawasan Konservasi Maritim”, 10/10/2019.

11. Bali Tolak Reklamasi 28/05/2020

$\mathrm{URL}=<$ https://www.facebook.com/forbali13/posts/akhirnya-terbukti-kelestarian-telukbenoa-adalah-penyelamat-banyak-orangdi-masa-/3487950074566851/>

12. Wisata Kuliner Bali: Bubur Seafood di Tanjung Benoa Badung Bali. TEMPO 24/01/2021 URL=<https://travel.tempo.co/read/1426230/wisata-kuliner-bali-buburseafood-di-tanjung-benoa-badung-bali/full\&view $=$ ok $>$ 